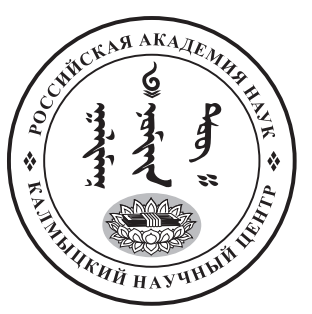

Published in the Russian Federation

Oriental Studies (Previous Name: Bulletin of the Kalmyk Institute

for Humanities of the Russian Academy of Sciences)

Has been issued as a journal since 2008

ISSN: 2619-0990; E-ISSN: 2619-1008

Vol. 14, Is. 3, pp. 606-625, 2021

Journal homepage: https://kigiran.elpub.ru

УДК / UDC 398

DOI: 10.22162/2619-0990-2021-55-3-606-625

\title{
О переводе двух песен эпоса «Гесер» Б. Бергманом
}

\author{
Бембя Леонидович Митруев ${ }^{1}$
}

${ }^{1}$ Калмыцкий научный центр РАН (д. 8, ул. И. К. Илишкина, 358000 Элиста, Российская Федерация) научный сотрудник

iD 0000-0002-1129-9656. E-mail: bemitrouev@yahoo.com

(C) КалмНЦ РАН, 2021

(С) Митруев Б. Л., 2021

Аннотация. Введение. В 1802-1803 гг. Бениамин Бергман совершил путешествие в калмыцкие степи для сбора исторического, литературного и фольклорного материала о калмыках и калмыцкой культуре. Результатом этого путешествия стала публикация в 1804-1805 гг. в Риге 4-томного издания «Nomadische Streifereien unter den Kalmüken in den Jahren 1802 und 1803» («Кочевнические скитания среди калмыков в 1802-1803 годах»), до настоящего времени представляющего собой важный источник информации о культуре и быте калмыков XVIII-XIX в. Среди переводов различных текстов, опубликованных в этом четырехтомнике, находится перевод с калмыцкого на немецкий язык двух песен эпоса «Гесер». Этот перевод представляет собой самый ранний перевод песен «Гесера» на европейский язык. Цель статьи. Немецкий перевод Б. Бергмана часто упоминается в научных работах, однако эти песни не были переведены полностью на русский язык. Материалом данного исследования является немецкий перевод двух песен эпоса «Гесер», опубликованный в «Кочевнических скитаниях среди калмыков в 1802-1803 годах». Результаты. Для того чтобы упростить исследователям, занимающимся ойратско-калмыцким «Гесером», доступ к материалу песен, переведенных Б. Бергманом, в данной статье представлен их научный перевод на русский язык. Кроме того, в статье рассматривается вопрос о природе оригинала песен, с которого был сделан перевод. До последнего времени существовало мнение, что основой для перевода песен был устный пересказ этих песен. Однако данные, рассматриваемые в исследовании, дают основания для гипотезы о письменном характере ойратского оригинала переведенных песен. Помимо перевода глав «Гесера», в данной статье выдвигается гипотеза о письменном характере оригинала источника, послужившего основой для перевода Б. Бергманом.

Ключевые слова: Калмыкия, «Гесер», песни, тодо бичг «ясное письмо», Б. Бергман Благодарность. Исследование выполнено при финансовой поддержке в форме субсидии из федерального бюджета, выделяемой для государственной поддержки научных исследований, проводимых под руководством ведущего ученого (проект № 075-15-2019-1879 «От палеогене- 
тики до культурной антропологии: комплексное интердисциплинарное исследование традиций народов трансграничных регионов: миграции, межкультурное взаимодействие и картина эпоса мира»).

Для цитирования: Митруев Б. Л. О переводе двух песен эпоса «Гесер» Б. Бергманом // Oriental Studies. 2021. T. 14. № 3. C. 606-625. DOI: 10.22162/2619-0990-2021-55-3-606-625

\title{
Two "Geser" Songs Translated by Benjamin Bergmann: Russian Translation and Discussion
}

\author{
Bembya L. Mitruev ${ }^{1}$
}

${ }^{1}$ Kalmyk Scientific Center of the RAS (8, Ilishkin St., 358000 Elista, Russian Federation) Research Associate

iD 0000-0002-1129-9656. E-mail: bemitrouev@yahoo.com

\author{
(C) KalmSC RAS, 2021 \\ (C) Mitruev B. L., 2021
}

\begin{abstract}
Introduction. In 1802-1803, Benjamin Bergmann made a trip to the Kalmyk steppes to collect historical, literary, and folklore material on the Kalmyks and the Kalmyk culture. The result of this journey was the 1804-1805 publication of "Nomadische Streifereien unter den Kalmüken in den Jahren 1802 und 1803" (Nomadic wanderings among Kalmyks in 1802-1803) in Riga, which up to the present day has not lost its importance as a source of information on the culture and life of the Kalmyks in the $18^{\text {th }}$ and $19^{\text {th }}$ centuries. The four-volume work contains translations of various texts from Kalmyk into German, including the two songs of the "Geser" epos. This is in fact the earliest translation of "Geser" songs into a European language. Data. The German translation of the two "Geser" songs published by Bergmann in his work has been used as the material for the present research. The aim of the article. Bergmann's translation of the songs is often mentioned in scholarly publications, but so far, no Russian translation of the songs in full has been made. To facilitate the research of the Oirat-Kalmyk "Geser" and especially of the songs in question, this article presents their scientific translation into Russian made by the present author. Also, the article discusses the character of the Kalmyk originals of the epic songs. So far it has been believed that an oral retelling was the source for the German translation of the songs. However, there is sufficient evidence for a new hypothesis because the analysis of the data undertaken in this study indicates that apparently there was a written Oirat source for the translation. Conclusions. Besides the complete Russian translation of the "Geser" sagas offered here, the article puts forward the hypothesis of the written nature of the original source, which served as the basis for Bergmann's German translation.
\end{abstract}

Keywords: Kalmykia, "Geser", songs, Clear Script, Todo bichig, B. Bergmann

Acknowledgements. The reported study was funded by government grant in the form of federal budget subsidy aimed to support scientific research directed by the Leading Scientist — project name 'From Paleogenetics to Cultural Anthropology: Comprehensive Interdisciplinary Research of Peoples and Traditions of Cross-Border Regions - Migrations, Cross-Cultural Interactions and Worldviews' (no. 075-15-2019-1879).

For citation: Mitruev B. L. Two "Geser" Songs Translated by Benjamin Bergmann: Russian Translation and Discussion. Oriental Studies. 2021. Vol. 14 (3): 606-625. (In Russ.). DOI: 10.22162/26190990-2021-55-3-606-625 


\section{Введение}

Бениамин ${ }^{1}$ Фюрхтеготт Бальтазар фон Бергман (нем. Benjamin Fürchtegott Balthasar von Bergmann; 1772-1856) - лютеранский пастор и исследователь, в период с 1799 по 1803 гг. дважды посетивший Сарепту르 и калмыцкие степи в ходе своих путешествий по России.

Находясь в Сарепте, Б. Бергман познакомился с евангелистскими братьями, от которых он узнал о калмыках, их языке и культуре и стал изучать калмыцкий язык под руководством Конрада Нейца [Митруев 2020: 186-187].

Итогом его пребывания среди калмыков стала публикация в Риге в 18041805 гг. четырехтомного труда «Nomadische Streifereien unter den Kalmüken in den Jahren 1802 und 1803» («Кочевнические скитания среди калмыков в 1802-1803 годах») [Митруев 2020: 192]. Среди богатого материала, опубликованного Б. Бергманом в этих четырех томах, находятся перевод на немецкий тринадцати рассказов «Сиддхи кюра», подробное описание жизни и обычаев калмыков «Калмыки между Волгой и Доном. Описание обычаев», перевод одной из глав калмыцкого эпоса «Джангар» «Героическая песня из Джангариады» и перевод двух глав из эпоса «Гесер» ${ }^{3}$ «Богдо Гесер-хан. Монгольское религиозное сочинение в 2 кни-

1 Бениамин Густавович Бергман (другой вариант имени - Вениамин) - пастор, писатель, издатель и переводчик, автор самой ранней европейской документированной записи калмыцкого эпоса «Джангар» и эпоса «Гесер». В российской научной литературе встречаются разные варианты написания имени этого исследователя: Бениамин, Вениамин, Бенджамин. Однако так как Benjamin Bergmann был немецкого происхождения, наиболее правильно писать его имя в соответствии с немецким произношением: Бениамин.

${ }^{2}$ Сарепта - бывшая немецкая колония, вошедшая в административную черту г. Волгограда в 1931 г.

${ }^{3}$ В историографии встречаются два варианта написания названия этого эпоса: «Гесер» (см., напр.: [Неклюдов, Тумурцерен 1982; Өөрд Геср 2014] и «Гэсэр» [Чагдуров 1980]). В данной статье мы используем первое написание. гах». Более подробно биография Б. Бергмана представлена в статье «Б. Бергман и его труд о калмыках и калмыцкой культуре» [Митруев 2020].

\section{Перевод песен «Гесера»}

Во время своего пребывания в калмыцких степях Бениамин Бергман перевел на немецкий язык две песни, которые были опубликованы в третьем томе «Кочевнических скитаний среди калмыков в 18021803 годах» под заголовком «Богдо Гесер-хан. Монгольское религиозное сочинение в 2 книгах» - «Bokdo Gässärchan. Eine mongolische Religionsschriftin 2 Büchern» [Bergmann 1804: 232-284]. Эти «две книги» представляют собой перевод глав эпоса «Гесер» - VIII главы «Оживление богатырей» и IX главы «Сражение Гесера с Ангдулма-ханом», перевод этих глав представлен в приложении к данной статье.

Эти две главы «Гесера», циркулировавшие в виде отдельной рукописи, часто носили самостоятельное название, что имело целью подчеркнуть самостоятельность произведения, которое фактически представляло собой часть целого цикла о «Гесере» [Хундаева, Бадмацыренова 2016: 169].

Большое количество рукописей отдельных глав «Гесера» на ойратской письменности тодо бичг 'ясное письмо ', хранящихся в разных библиотеках и фондах мира, указывает на то, что эти главы «Гесера» были популярны среди ойратов, проживавших в разных уголках мира.

Почему Б. Бергман характеризовал песни эпоса «Гесер» как «религиозное сочинение»? Одни и те же произведения монгольской литературы и фольклора могут причисляться к различным жанрам. Это явление можно объяснить нечеткостью жанровых определений и синкретизмом многих источников старой монгольской литературы [Хундаева, Бадмацыренова 2016: 169].

Предположительно, причина, по которой Б. Бергман перевел название двух песен «Гесера» как «религиозное сочинение в двух книгах», заключается в том, что название включало в себя слово «судур» или «цадиг», подобно тому, как в случае с «шойтеровской» рукописью об Андулма-хане [Хундаева, Бадмацыренова 2016: 169]. 
Причина популярности повествования о сражении Гесера с Ангдулма-ханом заключается в том, что в этом повествовании разрабатывается исключительно воинская тематика, важное место занимает описание воинского похода и сражения с врагом. Важную роль играют сам Гесер и его богатырь Дзаса Шикер [Неклюдов 1984: 195-196].

Список рукописи этих двух глав, написанный «ясным письмом» (тодо бичиг), хранится в архиве Калмыцкого научного центра РАН под шифром С(Калм) Г431, 12500 [НА КалмНЦ РАН].

На первом листе рукописи дано ее название: «Гесер богдо хаани туужи». Рукопись содержит VIII главу ойратской версии «Гесера», известную под названием «Оживление богатырей», и IX главу «Сражение Гесера с Ангдулма-ханом». Факт нахождения этой рукописи в Калмыкии свидетельствует о том, что письменный текст этих двух песен «Гесера» циркулировал на территории Калмыцкой степи.

Списки «Гесера» на «ясном письме» были известны российским исследователям, которые использовали их в своих трудах. В 1896 г. А. М. Позднеев в девятом томе Записок Восточного Отделения Императорского Русского Археологического Общества опубликовал текст на тодо бичиг и перевод на русский язык IX главы «Сражение Гесера с Ангдулма-ханом», назвав ее «Сказка про сраженіе Гесеръ-хана съ Андалмой» [Позднеев 1896].

В «Грамматике калмыцкаго языка» А. Попова опубликован «Отрывок из повести о Кессеръ-Ханъ», представляющий собой отрывок из седьмой песни, название которой С. А. Козин перевел как «Гесер в аду» [Попов 1847: 377-379].

Все упомянутые отрывки песен «Гесера» на тодо бичг ('ясное письмо') были получены авторами в Калмыцкой степи, что указывает на популярность этого сказания среди калмыков в XVIII-XIX вв.

Перевод Б. Бергмана был широко известен исследователям «Гесера» по всему миру. В предисловии к своему немецкому переводу эпоса «Гесер» Я. И. Шмидт пишет, что Б. Бергман в «Кочевнических скитаниях среди калмыков в 1802-1803 годах» предоставил перевод на основе калмыцкого оригинала [Schmidt 1839: VII] и что имени Буянтик в версии Б. Бергмана соответству- ет Буйдонг из монгольской версии, переведенной им; имени ханши Альмур - Ашу Мерген, а Сяхли - Санглун [Schmidt 1839: VII-VIII].

Кроме того, Я. И. Шмидт пишет, что слово «хошочи», которое Б. Бергман перевел как «безрассудный» или «отчаянный», имеет значение «командующий военным подразделением», от хошигу — «военное подразделение» [Schmidt 1839: VII-VIII]. Вероятно, Я. И. Шмидт был знаком с калмыцкой версией «Гесера», с которой работал Б. Бергман, так как Б. Бергман опубликовал лишь свой перевод без оригинального калмыцкого текста «Гесера», а без знакомства с текстом калмыцкого «Гесера» Я. И. Шмидт не смог бы сделать такие замечания.

Примечательно, что Е. Ф. Тимковский в первом томе своей книги «Путешествие в Китай через Монголию в 1820 и 1821 годах» разместил текст двух рассматриваемых здесь песен «Гесера» на русском языке [Тимковский 1824: 280-297]. Скорее всего, они представляют собой перевод с немецкого текста Б. Бергмана. На это, в частности, указывает то, что в его тексте второй песни герои описываются как «отчаянные», определение, о котором писал Я. И. Шмидт.

Я. И. Шмидт также пишет, что волжские калмыки называют «Малым Гесером» свой вариант «Гесера», в отличие от переведенного им монгольского эпоса, которого, как он думает, уже нет у волжских калмыков, но о существовании которого они хорошо знают. Он пишет, что этот так называемый «Малый Гесер» также хорошо известен монголам; однако они считают его всего лишь восьмой главой «саги» о Гесере [Schmidt 1839: VIII].

Я. И. Шмидт сообщает, что в богатой коллекции Русской академии наук есть монгольский экземпляр [«Малого Гесера»], который - без первой книги Б. Бергмана (т. е. 8-й главы «Гесера»), начиная со второй книги «саги» (т. е. 9-й главы «Гесера»), - рассказывает о битве Гесера с пятнадцатиглавым гигантом.

Эта первая книга из текста Б. Бергмана, так называемого «Малого Гесера», - не что иное, как краткое изложение некоторых более ранних событий, повествует о воскрешении костей тридцати героев, недавно павших в войне с шарайголами, для их 
повторного появления на сцене в борьбе с пятнадцатиглавым гигантом. Я. И. Шмидт пишет, что легко увидеть, что эта восьмая глава, или так называемый «Малый Гесер», относится к более позднему времени, когда героическая «сага» уже сложилась и является дополнением, лишь слабо связанным с основной «сагой» [Schmidt 1839: VIII].

Другой известный исследователь «Гесера» С. А. Козин в предисловии к своему переводу «Гесера» пишет: «Б. Бергман, опубликовавший в 1802 г. немецкий перевод двух песен Гесериады, по калмыцкому изводу, не обинуясь причислял Гесериаду к религиозным книгам буддистов. Стиль перевода Бергмана (VIII и IX песен) с особенной выразительностью подчеркивает эту его концепцию» [Козин 1935: 9].

По всей видимости, С. А. Козин считал текст «Гесера», переведенный Б. Бергманом, «изводом», что предполагает его письменную природу.

Интересно отметить, что И. С. Брагинский в своей статье говорит о том, что С. А. Козин перевел «вторую часть» Гесериады, песни 8-13, но перевод не был опубликован [Брагинский 1955: 27].

Вальтер Хайссиг в книге «Гэсэроведение. Исследования повествовательного материала в „новых“ главах монгольского цикла Гэсэра» пишет: «С открытием версии глав VIII-IX у волжских калмыков в 1802/03 г. Бениамином фон Бергманом мы получаем, однако, подсказку о времени возникновения частей цикла монгольского Гесера. Бергман четко идентифицирует свой оригинал как „Богдо Гесер-хан. Монгольское религиозное сочинение в двух книгах“, но без записи, было ли это „религиозное сочинение“ записано монгольским или калмыцким письмом, используемым с 1648 года, которая облегчила бы датировку» [Heissig 1983: 514].

Таким образом, В. Хайссиг также не испытывал сомнений относительно письменной природы источника Б. Бергмана.

В ходе изучения перевода на немецкий язык двух указанных песен мы пришли к заключению, что Б. Бергман обладал достаточным знанием калмыцкого языка, чтобы самостоятельно осуществить письменный перевод. Перевод Б. Бергмана очень подробный, в нем сохранено множество деталей, что позволяет предположить, что перевод был сделан с письменного источника.

При сравнении перевода девятой песни, выполненного Б. Бергманом, с переводом А. М. Позднеева и ойратским текстом рукописи из фонда Калмыцкого научного центра РАН [НА КалмНЦ РАН] обнаруживается большое сходство между переводами Б. Бергмана и А. М. Позднеева, хотя перевод Б. Бергмана несколько короче и имеет ряд расхождений с переводом А. М. Позднеева. Для примера мы приводим некоторые из них ниже в таблице.

\begin{tabular}{|c|c|}
\hline Перевод Б. Бергмана & Перевод А. М. Позднеева \\
\hline 33000 миллионов обыкновенных воинов & 33,300,000 войска \\
\hline разбил 500 миллионов царств & $\begin{array}{l}\text { подчинил себе население пяти провинций } \\
\text { местности }\end{array}$ \\
\hline Тук & Так \\
\hline 500 миллионов земель... & пяти провинций \\
\hline Какой хан Джампутиба восстает против него? & «есть ли в этом царстве хан выше меня?!» \\
\hline $\begin{array}{l}\text { Центр его тела защищают четыре могучих } \\
\text { тэнгрия. }\end{array}$ & $\begin{array}{l}\text { в срединной части своего тела он снабжен (телом) } \\
\text { четырех еретических гениев }\end{array}$ \\
\hline $\begin{array}{l}\text { Верхняя часть тела - восемь видов сил } \\
\text { тьмы... }\end{array}$ & $\begin{array}{l}\text { а в нижней части тела исполнен силами восьми } \\
\text { ракшасов }\end{array}$ \\
\hline $\begin{array}{l}\text { Триста просторных крепостей окружают его } \\
\text { обитель }\end{array}$ & дом, в котором он живет, — трехбашенный город \\
\hline $\begin{array}{l}\text { Его жена Падма Рака сияет, как золотисто- } \\
\text { желтое солнце светит на его... }\end{array}$ & $\begin{array}{l}\text { жена его - прелестная ханша, по имени Бадма- } \\
\text { рага, обладает красотою, превосходящей свет } \\
\text { золотых солнца и луны; }\end{array}$ \\
\hline «Нас не заботит отдаленность его царства». & $\begin{array}{l}\text { вообще же, в силу дальности расстояния, я не } \\
\text { узнал его как следует }\end{array}$ \\
\hline
\end{tabular}




\begin{tabular}{|l|l|}
\hline Тогда герои Шумар и Нанзон молвили следую- & Нанзан и Шумар, преклонив колена, говорят ав- \\
щее: «Твоя речь удовлетворяет все девять же- & густейшему повелителю десяти стран: «О, счаст- \\
ланий, посланный судьбой Властелин. Приго- & ливый и августейший наш, произносящий речи, \\
товившись, запрыгни на волшебного гнедого и & способные удовлетворить девять пожеланий! О, \\
собери героев в поход. Почему мы мешкаем?». & Донроб августейший наш, превозмогающий всех \\
Когда она сказала так на коленях... & 3лобных десяти стран! Что было бы, если бы сел \\
& ты на своего умного, гнедого коня, надел свои при- \\
& готовенные, драгоценные, военные доспехи, при- \\
& казал следовать за собою своим готовым тридцати \\
& богатырям, да поскорее отправился?». И с этими \\
& словами они поклонились августейшему. \\
\hline
\end{tabular}

При сравнении с ойратской рукописью заметно, что некоторые места в переводе были упрощены для облегчения понимания западным читателем. Например, слову suburqan в ойратской рукописи соответствует немецкое слово vest, означающее «замок». Естественно, что Б. Бергман видел в степи множество субурганов и знал о том, что это такое, но, видимо, для того чтобы сделать понятным свой перевод тем, кто

\section{$\left[233^{4}\right]$ Богдо Гесер-хан}

\section{Первая книга}

Богдо Гесер-хан был рождён, чтобы истребить корень десяти видов зла ${ }^{5}$. Правящий во всех десяти небесных регионах, храбрый, как лев, Богдо уничтожил магическими проявлениями двенадцатиглавого Мангаса $^{6}$, который намеревался поглотить все на Джампутибе, забрал Арулу구, возвышенную жену, и стал жить в золотом жилище двенадцатиглавого Мангаса. Арула, возвышенная супруга, вероятно, была одной из милосердных богинь, но из-за того, что ненависть наполнила её душу, [234] она смешала волшебное зелье, вручила его Богдо и произнесла эти слова: «Правитель всех 10 регионов неба, ты рождён разрушителем десяти видов зла, ты единолично преследовал и убил двенадцатиголового Мангаса, ты поселился в его золотом жилище. Радость твоей супруги [Арулы] велика. Соблаговоли, мой Богдо, попробовать этого напитка». Хотя Гесер-хан обычно помнил обо всех обстоятельствах, едва он попробовал этот на-

${ }^{4}$ Цифры в квадратных скобках относятся к нумерации страниц в немецком издании.

${ }^{5}$ Корень десяти видов зла. Этот оборот речи относится к десяти монголо-тибетским запретам, направленным именно против морального зла.

${ }^{6}$ Мангас - род злых духов.

${ }^{7}$ Арула — жена убитого Мангаса. не знаком с такими реалиями калмыцкого быта и религии, он использовал переводческий прием симплификации.

Ниже приведен перевод двух песен из «Гесера» на русский язык, выполненный с немецкого перевода Б. Бергмана.

\section{Перевод}

(В сносках представлен перевод сносок из оригинального немецкого перевода)

питок, как тотчас он все забыл. Богдо провел двенадцать лет в земле двенадцатиголового мангаса. Три хана из Шарайгольского царства приблизились к золотой земле Нулум $^{8}$, разрушили страну, рассеяли народ; но Гесер-хан не знал об этом.

Тогда три прославленные сестры правителя [Гесера] посмотрели с небес и так молвили с наполненными печалью сердцами: «Волшебное зелье Арулы сделало непобежденного побеждённым. С помощью волшебных сил Шарайгольское царство было основано Гесер-ханом, прежде чем он отправился сражаться с двенадцатиголовым мангасом. [235] Ты пришел на землю двенадцатиголового мангаса и все там забыл». Так они сказали, и написали послание на наконечнике оперенной стрелы Зесе-[Шикера], и отправили стрелу к правителю [Гесеру]. Теперь, когда правитель заметил послание на стреле, он сказал: «Это написал Зесе, мой брат». Сказав так, правитель [Гесер] вспомнил о произошедших событиях. Но Арула, возвышенная жена, сказала заботливо: «Ты болен, мой Богдо (Сиятельный)». Так молвив, она дала ему волшебное зелье. Не успел правитель попробовать напиток,

8 Земля Нулум, которую мы называем Шарайгольское царство, была основана Гесер-ханом, прежде чем он отправился сражаться с двенадцатиголовым мангасом. 
как он снова все забыл. В царство Мангаса снова явились три прославленные сестры и произнесли с печалью следующие слова: «Верхняя часть твоего тела оберегалась всеми богами десяти областей. - Где твоя божественная жена, мой Гесер? Средняя часть твоего тела оберегалась четырьмя могучими тенгриями. Где твои тринадцать двухэтажных храмов? Где твой драгоценный талисман? Где все это, мой дорогой? Нижняя часть твоего тела чортен 88 Бурханов. - Где твоё [236] чудесное жилище, мой Гесер? Где твоё второе я - Зесе Шикер, твой брат? Где герой Шумар? Где юный Нанзон с крепкой силой? Где же 30 смельчаков ${ }^{9}$, где 300 героев? Где победитель восемь раз восемидесяти мангасов, старый восьмидесятилетний Царгин? Где три племени широко распространившегося народа? Три хана Шарайгольского царства уничтожили все, а ты и не слышал об этом, потому что заклинание Арулы одолело тебя. Сейчас же садись на волшебного гнедого».

Когда три прославленные сестры так молвили, правитель избавился от [действия] волшебного зелья и снова вспомнил о том, что случилось. Тогда он издал львиный рык так, что земля задрожала, завертелся, как вихрь: в восемьдесят восемь раз больше золотого жилища и в три раза больше стены города. Все было уничтожено пламенем, а правитель забрал возвышенную супругу Арулу, и вскочил на волшебного гнедого, и вернулся в свою страну.

[237] Создав тысячу хубилганов, он уничтожил правителей всего Шарайгольского царства, взял божественную супругу и снова установил себя в городе с тринадцатью двухэтажными храмами и 108 просторными крепостями.

Восьмидесятилетний Царгин подошел к правителю десяти областей неба в окружении дочерей и детей героев. «Вот» (сказал правитель), - «Вот и пришли мои герои». Божественная супруга ответила следующими словами: «Это приближается старый Царгин с дочерями и детьми героев». Так она сказала, и правитель помрачнел, встал с могучим возгласом, начал вспоминать своих героев: «Ты, ястреб

${ }^{9}$ Смельчаки и герои. Для первых в оригинале стоит слово «хошучин», а для вторых «баатур». Баатуры настолько храбрее обычных воинов, насколько хошучины храбрее баатуров. среди людей, твое благородное сердце устремляется ко всем, мой брат, мой дорогой Зесе Шикер, где ты? А ты, орел среди людей, который, не колеблясь, как слон, отбросил все назад, ты, мой великолепный Шумар, где ты? А ты, сокол среди людей, одаренный каменным сердцем, с самого начала дал мне силы, ты, мой Буянтик, где ты? Львиный коготь правителя, подобный [238] соколу, схватившему добычу, раздавив её с силой 88 человек, мой пятнадцатилетний Нанзонг, где ты? Ты, подобный свирепому тигру, всепобеждающий Барс ${ }^{10}$, мой герой с каменным сердцем, где ты?». Так он говорил громким и чистым голосом, вспоминая исчезнувших героев, и вихрем трижды облетел по кругу стены.

Посредством облаков благовоний сын Хурмусты вновь укрепил мир и начал с этими словами: «Седлайте волшебного гнедого, украсьте его требуемыми драгоценностями. Теперь я ищу останки моих героев, так покажи мне, Царгин, место, скрывающее кости». Когда он сказал это, Царгин, склонившись, произнёс такие слова: «Моя душа была затуманена, так что я все забыл. Я достиг берега реки Хаттун, когда Зесе Шикер исчез, и я его более не видел». [239] Старый Царгин едва мог говорить со слезами на глазах, и правитель в печали едва слышал его слова. Затем правитель взошёл на поле боя героев, а Царгин направо и налево (бредя зигзагом) вел большого буланого коня позади правителя. На месте поля битвы раздавались громкие стенания повелителя. При виде костей героев Барса и Буянтика правитель упал на землю без чувств. Затем старый Царгин, видя правителя, лежащего на костях, произнес следующие слова: «Как же, Богдо! Ты лежишь на костях героев! Наполовину ты кажешься таким же безжизненным, как мертвец; наполовину ты кажешься живым, судя по твоим стенаниям. Правитель всех десяти регионов неба, очнись! Не подобает лежать на их костях». Так он сказал, и, вырывая ${ }^{11}$ волосы из своей бороды, он привел правителя в чувство. Затем Гесер-хан повел взглядом туда и сюда. Он лежал по-

${ }^{10}$ Барс. Сравнение героя с тигром, несмотря на игру слов, в оригинале более ярко, чем в переводе, потому что слово «барс» на монгольском означает «тигр».

${ }^{11}$ Versengend - буквально «подпалив». Прим. переводчика. 
среди костей героев Барса и Буянтика. Кроме того, правитель заметил две огромные кучи костей и произнес следующие слова: «Это кости несравненных героев Нанзонга и Шумара». [240] Так он заговорил и снова чуть не лишился чувств. Но душа Нанзонга стала львом, а душа Шумара - слоном, и правитель вернулся к жизни. Глядя на слона и льва, правитель издал громкий возглас и, обнимая слона и льва, поблагодарил богов всех десяти регионов, и, рыдая, он произнес следующие слова: «Вы, мои несравненные герои! Вы, Нанзонг и Шумар, — моё второе „я“! И ты, мой брат, дорогой Зесе Шикер! И ты, яростный среди множества людей, бушующий Барс! С раннего детства вы давали мне силы. Ты был светильником, освещающим ночь, дорогой Буянтик, и вы, все мои герои, и вы, мои священники, и мой народ, вы стояли непоколебимо, как скала. Правда, я - правитель Богдо, но в то время, когда я победил двенадцатиголового мангаса, я сам был побежден волшебным зельем Арулы». Так он говорил ясно и громко. Как на небесах синий дракон посылает гром на землю, так же звучали стенания правителя. Затем души героев, приняв вид слонов, тигров и волков, трижды обошли вокруг правителя, плача. [241] Три прославленные сестры правителя, услышав стенания, покинули жилище Хурмусты и произнесли следующие слова: «Богдо Гесер-хан был рожден, чтобы уничтожить корень десяти видов зла, чтобы править во всех десяти областях неба. Теперь его окружают души героев. Снова и снова видит [их], и увеличивается его горе. Снова и снова думает о [них], и преумножаются его стенания. Кости героев, наваленные друг на друга, окружают правителя, словно стены. Воды реки Хаттун протекают сквозь кости шарайгольских ханов».

Затем три прославленные сестры так [обратились] к правителю: «Милый брат! Не приличествует тебе стенать так постоянно. Так плачут лишь женщины». Так они молвили, и правитель всех десяти областей оставил слона и льва и начал [свою речь] следующими словами: «О, мои прославленные сестры, я оставил небесное царство по приказу Шагджамуни и по слову моего отца Хурмусты. Я отринул свои тело и кровь, тело с великими качествами, и спустился на землю во плоти. Но сколько [242] спутников меня сопровождало тогда? Сколько сопровождает меня теперь?». Так он произнес с новым плачем, и три прославленные сестры ответили: «Дорогой брат, не горюй! Не подобает тебе так жаловаться. Теперь мы возвращаемся к Хурмусте, твоему отцу, и скажем ему: „Судьба не допустит, чтобы души тридцати героев покинули жизнь правителя. То, что они всегда дают ему силы, решено самой судьбой“»».

Когда три сестры поднялись наверх к Хурмусте, предводитель преисполнился радости, и, видя, как дух оживляет его героев, он вспомнил всех богов и насладился благословленной пищей. Но, когда три прославленные сестры приблизились к Хурмусте, они молвили следующие слова: «Мы трое спустились вниз на землю, чтобы утешить нашего брата. Пока наш брат находился с величественной супругой Арулой в земле двенадцатиголового Мангаса, пришли разоряющие всё три хана Шарайгольского царства, разрушили великолепный храм и украли из золотого дворца дарующий жизнь талисман и божественную [243] супругу правителя, а тридцать героев были все убиты. Когда наш дорогой брат вернулся из земли Мангаса обратно, он преследовал врагов и достиг желанной цели. Теперь он вернулся в свою страну и в печали лежит на костях героев. Мы втроем тщетно пытались утешить его. Мы произнесли эти слова, чтобы доложить вам об этом». Тогда Хурмуста открыл Книгу судьбы, называемую «Найман Донгли», и начал читать следующие слова: «Гесер-хан со своими героями был отправлен по воле судьбы из царства тенгриев, но судьба запретила его героям умирать прежде своего правителя. Прежде Гесер-хан, верша свое дело, девять раз победил трех мятежных богов, которые однажды победили его на земле». Так сказал Хурмуста и предстал в окружении тенгриев пред ликом Шагджамуни и, поклонившись, произнес следующее: «Учитель богов! Тридцать его героев были отправлены посланниками на Землю. Его задание было выполнено, но, стеная, лежит Вершитель деяний на костях героев. Эти три [244] девы были с ним и принесли мне эти вести. Услышав это, я пришел, чтобы коленопреклоненно доложить вам об этом». После этих слов с благосклонной улыбкой Учитель богов начал с этих слов: «Почему же тогда Вершитель деяний ещё не пришел сюда? Прежде чем 
свершить это самое дело, он победил девять раз трех мятежных тенгриев. В то время три тенгрия так сказали ему: „Хотя ты победил нас девять раз, но один раз победим мы, когда мы трое примем рождение в виде трех могучих ханов, и тогда один раз мы обретем победу над тобой“. - Силой прежнего благословения это сбылось. Тогда взял учитель богов аршан из чёрной патры ${ }^{12}$ всех 1000 Бурханов, налил его в бумбу ${ }^{13}$ и, протянув чашу Хурмусте, произнес следующие слова: «Отправьте этот аршан Вершителю деяний [со словами]: „Если одну каплю этого аршана капнуть на кости героев, [245] тогда их кожа и их плоть снова обретут силу; если он прольет вторую каплю на восстановленное тело, тогда они снова обретут жизнь и душу. Если он прольёт третью каплю, то они снова полностью воскреснут“». Так молвил Учитель богов и затем начал говорить вновь: «Если это произошло, то необходимо ещё один раз дать выпить этот второй аршан, чтобы вернуть обратно в тело потерянного духа-хранителя вместе с пятью великими качествами (махамуд) и полностью обновить его». Так молвил Учитель богов и протянул аршан Хурмусте; Хурмуста взял аршан, передал его трем прославленным сестрам со следующими словами: «Так поговорите с Вершителем деяний о вашем деле: „Что случилось с тобой? Верхнюю часть твоего тела оберегают боги десяти областей, среднюю часть твоего тела защищают четыре могучих тенгрия, нижнюю часть тела -88 могучих Бурханов. Над поясом властвуют 80 богинь, Богдо Гесер-хан! Ты правишь во всех десяти регионах неба, ты - творение Хурмусты! Если бы ты всегда был со своими [246] героями, тогда бы тебе не пришлось сожалеть об их смерти“. Так поговорите с Вершителем деяний о его деле».

Когда Хурмуста так молвил, три прославленные сестры взяли аршан и спустились с небес с сильным громом, как будто бы вызванным двадцатью драконами. Когда правитель услышал этот шум, молвил следующее: «Вы, мои три прославленные сестры, что может означать ваш радостный ответ? Верно, мои тридцать героев возвра-

12 Бадир - священный сосуд, с которым всегда изображен первый из Бурханов.

13 Этот кувшин (бумба) используется для хранения святого аршана из шафрановой воды. щаются к жизни». Так он сказал, и старый Царгин ответил, обнажая свою голову, следующими словами: «Ты правишь во всех десяти регионах небес, разрушая корень десяти видов зла! Пред тобой склоняюсь девять раз со сложенными [у груди] руками! Пусть будет так в соответствии с твоей возвышенной речью! Пусть мои пожелания принесут мне радость! Пусть силой твоего благословения враги твои будут растоптаны под пятками твоих ног». Затем подошли три богини, и правитель десяти областей неба сказал следующие слова: «О, мои прославленные сестры, достигнута ли цель вашего путешествия?». [247] Так он спросил, и богини ответили следующее: «Мы бы не вернулись обратно, если бы мы ещё не достигли своей цели».

Когда Гесер-хан услышал такие речи, он обнажил свою голову, чтобы поклониться перед тремя богинями, но три богини произнесли следующее: «Не подобает тебе, дорогой, преклоняться перед нами». Так они говорили, и Гесер-хан ответил следующими словами: «Мягкие, как свет солнца, вы освещаете лучами все существа! Подобно Оточи Бурхану, появляетесь перед ними! Где бы я ни был, вы всегда следуете за мной тенью! Словно драгоценный талисман, вы способны исполнить все желания». Когда он склонился и, молвив так, сел на золотом троне, три прославленные сестры произнесли следующее: «Так сказал Учитель богов! „Судьба запретила его героям умирать раньше правителя. Когда Вершитель деяний, спустившись на землю, победил трех тенгриев девять раз, судьба решила, что три тенгрия в будущем смогут [248] нанести поражение один раз“. - Учитель богов продолжил далее: „Если ты брызнешь одну каплю этого аршана на кости героев, то их кожа и плоть снова обретут силу. Если ты брызнешь вторую каплю на восстановленные тела, тогда они снова обретут жизнь и душу. Если ты брызнешь третью каплю, то они снова полностью воскреснут“. Так молвил Учитель богов и пожаловал этот напиток аршана, который возвращает духа-хранителя души с пятью великими характеристиками тела». Когда правитель десяти регионов услышал эти слова, его десятикратно святая душа была наполнена солнечными лучами радости. «Речь Хурмусты - истинная правда, - сказал правитель, - Омрачённый 
магией Джампутиба, я был побежден, мои крепости были уничтожены; все из-за того, что я в течение семисот лет не помнил речь Шагджамуни, услышанную от отца. Совершенно истинна речь Хурмусты». Затем Гесер-хан встал, поклонился девять раз по девять перед Учителем богов и девять раз перед Хурмустой, своим отцом, и взял [249] святой аршан. Теперь же он пролил первую каплю на кости героев, чтобы дать силу их коже и плоти. Когда он пролил другую каплю, их тела и души были обновлены. Когда же он пролил третью каплю, они снова полностью воскресли, поднялись с земли и приняли позу молитвы. Они выпили второго аршана, и потерянный дух-хранитель вернулся обратно. Как будто они вернулись из путешествия домой, все тридцать героев встали и приблизились к правителю, и снова правитель со львиным рыком произнес следующее: «Из царства Хурмусты вы были отправлены со мной как мои спутники». Затем пришел Шумар, ястреб среди людей, а также пятнадцатилетний Нанзонг и Буянтик, знающий шесть языков, со всеми тридцатью героями и, ухватившись за кончик платья правителя, произнес следующие слова: «Правитель десяти регионов неба! Разрушитель корня десяти видов зла! Ты силен, как четыре пояса горы Сумеру! Ты властвуешь над всеми живыми существами, могучий Богдо! Когда ты увядал с Арулой, возвышенной супругой, в землях двенадцатиголового [250] Мангаса, приблизились три хана из Шарайгольского ханства. Зесе Шикер, твой брат, и все тридцать героев отправились против вражеских полчищ. Завязалась храбрая битва, храбрые воины были захвачены в плен. Тогда злобный принц Цотон вернулся от врага и обманул нас всех, но Зесе Шикер так сказал нам: „Разве вы не видели, как Цотон пошел к врагу? А теперь он вернулся и говорит обманчивые слова“. Так он сказал, и мы разошлись, все из-за обмана Цотона. Беду, вызванную Цотоном, невозможно передать словами. Когда правитель удалился, с нами все еще оставался Зесе Шикер. Не жалея своих жизней, мы вступили в гущу битвы и разрубили врагов до земли. Но количество врагов было велико, и мы не могли убить их всех. Говорят: „Давайте будем беречь свою жизнь“. Но бегство от врага покроет бесчестьем героев на тысячу лет. Не заботясь о своей жизни, мы все искали смерти. Теперь мы снова вернулись при помощи божественных сестер, благодаря Хурмусте, благословению божественного Учителя, [251] и благодаря тебе, правитель десяти регионов неба, мы снова воссоединились с тобой. Оставь же сейчас, правитель, плач».

Когда они говорили так на коленях, правитель преисполнился радости. «Но где же серый полосатый тигр, где падающий сокол, где синий дракон, посылающий молнии в небе, где ястреб среди людей, Зесе Шикер, мой старший брат?». Так он сказал, вспоминая о своем брате, и три раза издал крик, потрясший мир. Правитель собрал воскресших героев с тремя племенами людей, и праздник радости гремел, как море. Клубились облака благовоний, и два сияющих цветка линго проросли из земли. Никакие глаза не могли смотреть на них днём. Ночью они служили вместо светильников. Одетые в нетленные одежды, герои склонились перед правителем. По окончании трех месяцев радостных празднеств все вернулись домой. Львиная сила правителя воскресила героев. Все было завершено, а Богдо Гесер-хан жив, спокоен и счастлив.

\section{[252] Богдо Гесер-хан. Вторая книга}

Богдо Гесер-хан, правящий во всех десяти направлениях неба над духовенством, подобно солнцу, а над людьми, как скала. В земле Докуртиб ${ }^{14}$ правил Андулман-хан, обладавший чудесным телом с сотней рук и сотней глаз и совершенной дьявольской силой. Центр его тела защищали четыре мятежных тэнгрия. Верхняя часть тела была защищена восемью видами сил тьмы. У него насчитывалось 71 воплощения-хубилгана. Его приказам подчинялись 360 смельчаков, 3000 героев и 33000 миллионов обыкновенных воинов. Его желто-пегий конь был силен, как тринадцать драконов. На берегах земли Тук [253] он разбил 500 миллионов царств и послал князей местных жителей к Богдо Гесер-хану, чтобы передать ему эти слова: «С земли Докуртиб пришел Андулман-хан. Который из ханов Джампутиба поднимется против него? Мы те, кто был им побежден и подчинился ему. Ему подчи-

${ }^{14}$ Докуртиб. Монголы располагают вокруг горы Сумеру четыре основных и восемь второстепенных регионов мира. Последний регион, который населен мангасами, - это Докуртиб. 
няются 3000 героев. Его желто-пегий конь силен, как тринадцать драконов. До его царства в Докуртибе нам пришлось путешествовать пятнадцать лет».

Когда он так сказал, он дал каждому из трех князей и каждому из 300 спутников по 100 лошадей и сказал: «Путешествуя днем и ночью, вы достигнете царства через три года и вернетесь обратно через три года, но затем вам потребуется еще девять лет, чтобы приехать в мою страну».

По прошествии трех лет посланники добрались в землю Правителя и, приблизившись ко дворцу на расстояние, с которого может быть слышен голос, сделали девять по девять раз поклонов до земли. Люди увидели незнакомцев и сказали: «Из какой страны приехали эти незнакомцы?»

[254] Тогда Гесер-хан послал гонца, и чужестранцы так сказали гонцу: «Нас отправил Андулман-хан с берегов земли Тук к властелину десяти областей небес. Наши князья отправили следующее послание: „Из земли Докуртиба пришел Андулман-хан с 3000 героями и 33 миллионами обычных воинов, они завоевали наши 500 миллионов земель. Какой хан Джампутиба восстает против него? Мы, побежденные, подчинились ему“. Так [Андулман]-хан сказал, вернувшись домой, и послал гонцов в эту область». Как только гонцы точно передали Правителю [Гесеру] приказ своих ханов, Правитель собрал своих героев и обратился к ним со следующими словами: «Вы, наверное, слышали, что Андулман-хан покинул земли Тук как победитель. Как думаете, что нам теперь делать?» Смеясь, Шумар-герой ответил следующим образом: «Воистину мы слышали действительно прекрасные речи».

Когда он так говорил со смехом, мудрый Буянтик рассудительно молвил: «Почему, [255] мой Шумар, ты всегда смеешься? Пусть сначала говорит Правитель, мы выскажемся после». После того, как Правитель все обдумал, он сказал: «Как вы, мои герои, знаете, в царстве Докуртиб живет пятнадцатиголовый Андулман-хан с сотней рук и сотней глаз. Центр его тела защищают четыре могучих тэнгрия. Верхняя часть тела - восемь видов сил тьмы. У него насчитывается 71 воплощение-хубилган. Его желто-пегий конь силен, как тринадцать драконов. Триста просторных крепостей окружают его обитель. Его жена Падма-Рака сияет, как золотисто-желтое. Нас не заботит отдаленность его царства».

Тогда герои Шумар и Нанзон молвили следующее: «Твоя речь удовлетворяет все девять желаний, посланный судьбой Властелин. Приготовившись, запрыгни на волшебного гнедого и собери героев в поход. Почему мы мешкаем?».

Когда он сказал так на коленях, Правитель, улыбаясь, начал [со следующих слов]: «Орёл [среди] людей, мой Шумар, подожди! Ты, мой Нанзонг, с могучими орлиными крыльями, подожди! [256] Давайте подумаем, сколько воинов нам нужно».

Так он молвил, и, [стоя] справа на коленях, знающий шесть языков Буянтик начал со следующих слов: «Давайте отправим десять посланников и с каждым посланником десять миллионов всадников; и пусть они идут по своему пути днем и ночью. С собравшимися господами следуйте своему пути». Так он сказал, и правитель одобрил [его] речь.

Затем Шумар-герой повесил на сверкающий панцирь черный тяжеловесный лук вместе с колчаном с восемьюдесятью восемью широкопёрыми стрелами, подвесил сбоку меч длиной в девять саженей, сел на вороного коня и, приблизившись к Правителю, произнес следующие слова: «Наводящий ужас Правитель, я пойду против пятнадцатиголового Мангаса один. Он завоевал пятьсот миллионов наших стран, почему же мы мешкаем?».

Так он молвил, и правитель ответил так: «Храбрый Шумар, ты сказал совершенно верно».

Другие герои тоже в свою очередь вооружились, и войско правителя собралось. [257] Богдо услышал шум и сказал: «Ангдулман-хан пришел с войском».

Так он сказал, и Шумар-герой ответил: «То, что я думал, случилось». Сказав так, он достал свои меч длиной в девять саженей из своих ножен и поспешил на вороном коне. Но Правитель присмотрелся и узнал своих воинов. Тогда Буянтик приблизился к стремительному Шумару и сказал: «Ты ринулся, как яростный тигр!».

Шумар услышал голос Буянтика и, громко смеясь, придержал своего вороного коня. Тогда Нанзонг сказал следующие слова: «О, Шумар, сначала мы найдем во- 
йско Андулман-хана, а потом мы можем смеяться».

Пока они смеялись, собралось множество людей, тридцать отчаянных, Нанзонг и Шумар приблизились к Правителю и на коленях произнесли следующие слова: «Правитель десяти областей неба! Может быть, пятнадцатиголовый Андулман-хан и насчитывает 71 хубилган, но боги подарили тебе тысячу хубилганов. Так кто же может победить нас? Не нужно великое [258] количество воинов. Уже только твоих трехсот героев достаточно».

Так они молвили. Правитель одобрил речи Шумара и Нанзонга и обратился к Буянтику со следующими словами: «Буянтик, правильно или неправильно говорят эти двое?».

На эти слова Буянтик ответил: «Правитель десяти областей неба! Ваша светлость может решить сама».

После этого правитель приказал вернуться войскам обратно и приготовиться собраться в поход. Пока герои собирались в поход, Правитель намерился совершить поход, который обычно занял бы двенадцать лет, за двенадцать месяцев. Он оставил восьмидесятилетнего Царгина дома заботиться о своем народе и стадах. Но теперь старый восьмидесятилетний Царгин обратился к Правителю со следующими словами: «Богдо! Может, мне и восемьдесят лет, но я хотел бы увидеть великую войну. Когда Хурмуста-тенгери отправил тебя на Джампутиб, были предвозвещены два великих сражения. Первая война была с шарайгольскими ханами. Теперь приближается вторая война. Много дней я прожил, [259] мало их осталось мне. Поэтому дозволь, Богдо, мне пойти с тобой в бой».

Так ясно произнес старик, и правитель не мог удержаться от слез. Тогда подошел Нанзонг и сказал: «Ты всегда повиновался приказам Повелителя, почему же теперь ты поступаешь вопреки его слову?».

Старый Царгин ответил на эти слова: «Пятнадцатилетний Нанзонг, подумал ли ты обо мне? Твой восьмидесятилетний Царгин согбен старостью. Мой соловый конь едва щиплет старую траву. Седые волосы покрывают моё темя. Еще раз желаю биться я пред очами Правителя в твоей компании, мой Нанзонг».
Так говорил в слезах, и все герои плакали с ним. Тогда Богдо взял свою рубашку, и отдал её старику, и сказал: «Царгин, мой дорогой! Совершенно верно ты ведешь речи. Но ты всегда слушался моих слов, так что оставайся здесь и служи народу».

Так он молвил, и старый Царгин ответил следующее: «Совершенно верно ты сказал, Богдо. Когда я был молод, я всегда исполнял твои приказы, как же может теперь старый [260] Царгин нарушить их? Мои кости иссохли. Моя черная кровь застыла в моих венах. Возраст согнул меня. Я лишь хотел вступить в битву, чтобы умереть на твоих глазах. Ты говоришь: „У тебя нет сил, Царгин! Останься!“. Так как мои силы исчерпаны, я остаюсь».

Так ясно молвил старик и ушел с глаз Правителя. Однако, когда правитель начал поход против пятнадцатиголового мангаса, он сказал Улану и Буянтику следующее: «Отправляйтесь вперед. Но когда вы прибудете на вражескую землю, тогда скажите так: „Гесер-хан, правящий Джампутибом, наступает со своими армиями, чтобы отделить от тела все пятнадцать голов мангаса одну за другой“"».

Так он сказал, а Улан и Буянтик радостно сели на коней и достигли вражеской земли. Оба напали на белый табун хана, увели 11000 белых лошадей и с грохотом, так что земля под ногами задрожала, они унеслись с лошадьми прочь.

Когда Андулман-хан заметил дрожь земли, он сказал: «Кто бы это мог быть, [261] кто пришел? Ко мне не осмеливается подойти ни одно существо на земле. Это прибыл Хурмуста».

И пришли пастухи и доложили следующее: «Пришли грабители и забрали 11000 белых коней».

«Насколько сильно (спросил Андулман-хан) было войско?».

Пастухи ответили: «Сначала мы подумали, что их было более 10000 , и только затем мы узнали, что их было двое».

Тогда хан произнес эти слова: «Наверное, это князья, присланные злодеем Гесером». Так он рек, а затем обратился к героям Архаю и Шархаю: «Возьмите 1000 воинов и скорее отправляйтесь в погоню за бегающими. Но не убивайте их. Приведи их сюда живыми, а табун пригоните обратно». 
Когда он так сказал, Архай и Шархай и 1000 воинов погнались за героями.

Тем временем Улан и Буянтик с табуном достигли вершины Львиных гор и, выбрав одну лошадь, зарезали её. Затем оба, склонившись перед Правителем земли, [262] помолились. Буянтик, услышав громкий шум, сел на лошадь и посмотрел вниз с вершины Львиных гор. Когда он увидел героев Архая и Шархая с 1000 воинов, он сказал следующее: «Улан, садись на свою лошадь! Враги рядом».

Громко смеясь, Улан вскочил на лошадь и таким же образом оглянулся вокруг. Затем Буянтик сказал: «Если мы не победим, Улан, наши имена будут опозорены!» Когда он так сказал, Улан ответил: «О, дорогой Буянтик! Как можем мы не осилить эту кучку!». С этими словами он стегнул своего коня кнутом, обнажил свой черный стальной меч и с громким криком, вращая красными глазами ${ }^{15}$, он с грохотом понесся туда. Буянтик также стегнул своего коня кнутом и с грохотом поскакал. Тогда мужество героев Архая и Шархая испарилось. Улан и Буянтик воззвали к духу-защитнику Правителя. Буянтик так ударил героя Архая, что его голова, вращаясь, улетела вместе со шлемом. Улан одним ударом [263] меча отрубил обе руки героя Шархая. Но Буянтик сказал: «Нет, мой Улан, не убивай его!». После этих слов он одним взмахом своего меча срубил 1000 воинов.

Затем они расспросили героя Шархая, и Шархай-герой доложил то, что ему приказал Андулман-хан, а затем произнес следующее: «Вы, два небожителя, благоволите оставить меня в живых, молю вас». Тогда Буянтик так ответил: «Не подобает нам слышать такие слова, они уместны только по отношению к Правителю десяти областей. Оставим ли мы тебя в живых или нет, теперь это зависит от нас. Сейчас возвращайся обратно и так скажи хану: „Наводящий ужас Гесер-хан, правящий Джампутибом, приближается со своим войском, чтобы одну за другой срубить все головы пятнадцатиголового Андулман-хана и править его народом. Мы оба лишь слуги нашего хана и посланы сказать тебе эти слова“"».

Так они сказали, и привязали обрубки рук к ремню героя, и отправили его обрат-

${ }^{15}$ В оригинале героя зовут не просто Улан, но Улан Нидун, что значит «Красные глаза». но. Шархай-герой приблизился к [264] Андулман-хану и доложил следующее: «Мы думали, что будем биться с двумя людьми, но, ведя битву, мы думали, что их будто бы больше чем 10 000. Я был побежден и отправлен с этим донесением: „Ужасный Гесер-хан, правящий в Джампутибе, приближается к пятнадцатиголовому Ангдулман-хану, чтобы одну за другой отделить от тела все пятнадцать голов и править его народом“. Так меня послали передать вам эти слова».

Когда он так сказал, Андулман-хан всплеснул руками и произнес следующее: «Два героя, отправленные с тысячей воинов, были побеждены двумя людьми, а один воротился без рук и ног!». Сказав это, он убил Шархая-героя.

В этот момент Андулман-хан ударил в большой барабан и собрал все войско. Затем Андулман-хан ударил в малый барабан и собрал избранный отряд войска. Сам он встал среди своих трех тысяч героев и сказал: «Все вы, наверное, знаете, что надвигается злобный Гесер. Двое из его людей украли 11000 наших белых [265] лошадей. Я отправил в погоню этих двоих героев: Архая и Шархая, и 1000 воинов, но Арчай и Шархай и 1000 воинов были убиты. 11000 белых лошадей больше нет. Что же теперь делать?»

Так он молвил, и все герои молчали. Андулман-хан сказал: «Почему вы все молчите?». Тогда предводитель правого крыла, герой Хата-хара произнес: «Если бы мы не захватили землю Тук, то никакие враги не смогли бы приблизиться к нам. Гесер-хана сверху оберегают боги десяти областей, снизу - восемьдесят восемь могучих Бурханов. Четыре великих тэнгрия и сто восемь богинь охраняют среднюю часть его тела. Если злобный Гесер-хан действительно отправится на нас, тогда нам точно не будет покоя».

Так он молвил, и Зан-тушимэль - предводитель левого крыла и 360 смельчаков, произнес следующие слова: «Гесер-хан всегда был существом-хубилганом! Наш хан тоже. Так что без промедления необходимо сесть на коней и выдвинуться навстречу врагу». [266] Андулман-хан похвалил эти слова, сел на свою желто-пегую лошадь и, надев девятерной панцирь из золота, выступил впереди всей армии против врага. 
Улан и Буянтик прибыли с 11000 белых лошадей к правителю Гесер-хану и доложили следующее: «Мы оба выполнили приказы Правителя и вернулись с 11000 белыми лошадьми мангаса. Нас преследовали 1000 воинов и герои Архай и Шархай, когда мы с ними столкнулись, мы, помолившись духу-хранителю Правителя, убили одного из двух героев вместе с 1000 воинов. Другому же прикрепили обрубки рук к его ремню и привязали его к коню, чтобы отправить приказ Повелителя к мангасу. Затем мы вернулись обратно».

Так они доложили, и Правитель десяти областей неба сказал следующее: «Как может наш поход не увенчаться успехом, когда Улан и Буянтик благополучно вернулись! 11000 белых лошадей — счастливый знак». Так он сказал и повелел разделить лошадей между героями.

[267] Когда герои совершили путешествие длиной в три месяца, они увидели город Андулман-хана и произнесли такие слова: «Смотрите! Это город Андулман-хана». Тогда Правитель отпустил поводья волшебного гнедого коня. Герои, исполнившись радости, отпустили поводья лошадей и последовали за Правителем.

В то время, когда Гесер-хан надвигался на своих врагов, Андулман-хан увидел, что поверхность земли покрыта сотнями тысяч миллиардов [воинов], и произнес следующее: «Как! Не под поступью ли врага трясется земля?». Так он молвил, охваченный ужасом.

Затем Гесер-хан сказал своим героям следующие слова: «Словно камень, ваши сердца, мои герои! Правда, что количество врагов велико, но, если вы устанете убивать, тогда молитесь мне - Гесер-хан обладает в десять раз большими силами и освежит вашу мощь. Даже если вы покрыты ранами, обратитесь с молитвой - Гесер-хан может исцелить ваши раны без снадобий. Если вы мучаетесь в битве, изнемогая от жажды, тогда молитесь мне - Гесер-хан даст вам напиток аршан». [268] Так он сказал, и все герои наполнились радостью и обратились [к нему] со следующими словами: «Возвышенный Правитель всех десяти областей! Ты был рожден, чтобы уничтожить корень десяти видов зла! В тебе наше утешение».

Когда они, поклонившись, так сказали, Правитель одобрил эти слова и снова сел на коня. Доспехи Наводящего ужас с семью драгоценными камнями сияли, как солнце и луна. Через плечо висит черный тяжеловесный лук вместе со сверкающим колчаном. С левой стороны бряцает длинный стальной меч. Так Правитель надвигается на мангаса, чтобы вступить в битву. Громок, как грохот тысячи драконов, его голос. Девятицветная радуга засияла лучами на его шлеме, окруженном пятью крыльями Гаруди. Из ноздрей до неба вспыхивает божественное пламя. Его лоб подобен лику Махагалы ${ }^{16}$. Искры летят от копыт волшебного гнедого, от каждого его волоска исходит пламя. Так Правитель, держа в руке длинный стальной меч, несется на врага.

Все тридцать героев вскочили на коней, наполнившись радостью, будто они нашли вечный волшебный камень, [269] они кричат друг другу: «Будем храбры пред врагами!».

Шумар - орел [среди] людей, в сверкающем панцире, повесил по бокам черный тяжеловесный лук вместе с колчаном с восемьюдесятью восемью широкопёрыми стрелами и девятисаженный меч и сел на вороного коня; голос его громок, как двадцать драконов. Пятицветная радуга сияет вокруг его головы, как будто лик Очирвани. Искры летят от копыт коня. Ничего не слышит Шумар. Отпустив поводья, Шумар несется мимо Правителя на мангаса. Раньше остальных вражеских героев его узнал Хата-хара в сияющих доспехах с трехсаженным мечом в руке и поскакал к спешащему Шумару. Но, когда он увидел на лице героя сияние Очирвани, он был охвачен ужасом и не мог нанести ни одного удара мечом. Шумар же девятисаженным стальным мечом отсек голову героя вместе с его шлемом и привязал ее к хвосту своего коня. Он вытянул свой девятисаженный меч на девяносто девять саженей. Так бросился Шумар на врага [270] и каждым ударом своего меча разрубал 10000 воинов. Оглядываясь назад, Шумар еще глубже вошел в толпу врагов.

Правитель десяти областей неба в сопровождении тридцати героев издал крик, ужасный, как тысяча его драконов. Правитель сделал свой меч длиннее на пятнадцать сотен саженей и каждым ударом срубал несколько десятков тысяч [врагов]. Гесер-хан убил более одного десятка тысяч, владею-

\footnotetext{
${ }^{16}$ Один из ужасных богов монголов.
} 
щий шестью языками Буянтик -1 000 десятков тысяч; пятнадцатилетний Нанзонг тысячу и ещё несколько десятков тысяч; герой Барс - восемь десятков тысяч; герой Улан - пять десятков тысяч; герой Орса восемь десятков тысяч, а другие герои, срубив кто много, а кто мало, снова собрались рядом с Правителем.

Когда все собрались возле Правителя, отсутствовал только Шумар. «Где же наш Шумар? Верно, его убил Андулман-хан», когда сказал так Правитель, герои доложили: «Шумар неохотно возвращается из вражеского войска раззадоренный. Его огромный вороной конь стал темно-коричневым, [271] а стальная броня - красной, как огонь».

Так они сказали. Тут подъехал Шумар и со смехом молвил: «Наверное, вы голодны или испытываете жажду, что собрались все здесь». Так говоря, он сел рядом с Правителем и сказал: «Не было удовольствия в моем возвращении, но я вернулся, потому что не увидел Правителя».

Тогда Правитель ответил: «Орел [среди] людей! Будто камень, твое сердце, мой Шумар! Сколько врагов, по-твоему, ты сегодня убил?».

Так молвил Правитель, и Шумар со смехом произнес: «Я убил сто одну тысячу, а затем я вернулся».

Правитель сказал: «Насколько все еще сильно сейчас вражеское войско?».

Шумар доложил: «Вероятно, вражеского войска еще осталось триста три тысячи».

Когда он так сказал, Гесер-хан произнес: «Приготовьте аршан. Когда аршан снова укрепит наши силы, мы сядем обратно на коней». [272] Все выпили аршан, и Гесер-хан ринулся на Андулман-хана, а герои атаковали вражеское войско на обоих флангах. Когда Гесер-хан приблизился к мангасу, он отрубил пять голов огромным мечом, но головы мгновенно снова восстановились.

Зан-тушимэль вырвал с корнем дерево, которое не могут обхватить пять человек, и, размахивая им туда и сюда, отбросил всех обратно. Нанзонг и Шумар, с трудом победив, убили героя.

Правитель десяти областей неба снова отрубил пять голов мангаса, но мгновенно головы восстановились. Удивленный, Правитель опустил к земле свой меч. Тогда Андулман-хан разрубил Правителя от левого плеча до подошвы, но тело Правителя мгновенно снова восстановилось, и он произнес: «Хурмуста, мой отец, я не могу убить этого хана».

Так сказав, он стал молиться трем прославленным сестрам: «Три прославленные сестры! И вы, три могучих тэнгрия! С тех пор, как я [273] был послан моим отцом, Хурмустой, уничтожить корень десяти видов зла, не было у меня ни одного врага, подобного этому».

Три прославленные сестры услышали слова Правителя и доложили о том, что слышали, Хурмусте. Тогда Хурмуста молвил следующее: «Как Вершителю деяний, спустившемуся на Джампутиб, ему были предсказаны две великие войны. Он теперь ведет последнюю войну. Кто спустится, чтобы помочь ему?».

Так сказал Хурмуста, и три тэнгрия дали такой ответ: «Мы спустимся». Но Зесе Шикер подошел к Правителю и произнес следующее: «Правитель десяти областей уже начал биться с пятнадцатиголовым мангасом. Его сил не хватает, и сил трёх тенгриев недостаточно, чтобы победить вражеского хана. Я пойду посмотрю, что я могу сделать. Я уже был с Правителем прежде и знаю его дела». Хурмуста ответил на эти слова: «Очень хорошо, мой Зесе. Спустись». [274] Когда Хурмуста так сказал, Гимсун обратилась к своему мужу: «Ты уже покидал меня однажды, когда Правитель десяти областей был вдали от своей страны, и теперь, когда судьба воссоединила меня с тобой, ты снова меня оставляешь! Как же я останусь без тебя? Во второй раз Злодей Цотон причинит тебе несчастье, а я снова умру».

С вершины золотой башни Гимсун бросилась на землю и, возродившись богиней, воссоединилась с Зесе. Тогда Зесе Шикер сел на серого восьмикрылого коня. Повесив на плечо сверкающий колчан, наполненный оперенными стрелами, и черный тяжеловесный лук, Зесе [надел] сияющие доспехи. Удаляясь вместе со своей супругой Гимсун, он сказал: «Особенно вы, Хурмуста, а также все остальные, пребывайте в здравии и покое. Я же отправляюсь к Правителю десяти областей неба». Так он сказал и покинул царство богов. Цзаса Шикир посмотрел во всех четырех сторонах света на расстояние пяти дней пути и, наконец, обнаружил Правителя, [275] бьющегося с мангасом. Тогда 
Зесе так обратился к Гимсун, своей супруге: «Полагаю, мне не удастся приблизиться, чтобы порубить мангаса на куски. Душа ${ }^{17}$ вражеского хана находится в глазах. Если Правитель узнает обо мне, тогда его лицо омрачится».

Так сказав, он прицелился в глаза мангаca, находившегося на расстоянии пяти дней пути, и выпустил стрелу, которая пронзила глаз, в котором находилась душа. Подобно обрушивающейся горе, мангас упал со своей желто-пегой лошади.

Затем Гесер-хан произнес следующее: «Это была ваша работа, три прославленные сестры! Это была ваша работа, три прославленных тенгрия!».

Так молвив, он сдвинул волшебным кнутом уздечку желто-пегой лошади и, посмотрев, узнал стрелу. Взяв стрелу, он обнял её и произнес: «Этот [276] острый блестящий наконечник стрелы принадлежит твоей оперенной стреле, брат мой. Где ты находишься сейчас?».

Так он сказал, и Зесе Шикер отпустил поводья серого восьмикрылого коня, бросился с обнаженным мечом, и порубил, как овец, остатки вражеского войска, и рассеял их, как пепел, по ветру. Он сделал это одним ударом своего меча и повернулся к Правителю.

Теперь Правитель узнал дорогого [Зесе Шикера], мгновенно спрыгнул с волшебного гнедого в объятия брата и сказал: «Дорогой брат! Враги разрубили тебя на куски. Несравненный брат, куда ты сейчас направляешься? Откуда ты пришел?.

Тогда Зесе Шикер ответил следующее: «Правитель десяти областей неба, рожденный, чтобы уничтожить корень десяти видов зла! Пока ты побеждал двенадцатиголового мангаса, пришли три разрушающие хана из Шарайгольского царства. Тогда, не жалея тела и жизни, Зесе Шикер выступил против врага. Черная кровь текла из ран. Выпив из реки Хаттун, [277] я был побежден вражескими силами. По прошествии времени силой твоего благословения я снова родился в царстве Хурмусты, тут пришли три тенгрия и сказали следующее: „Внизу в

17 Монголы и калмыки называют жизнь и душу общим термином «амин» (монг. амин, калм. әмн). Этот термин мало отличается от двух латинских выражений «animus» и «anima».
Джампутибе Правитель со своими героями ведет изнурительную битву с пятнадцатиголовым мангасом“. Когда я услышал эти слова, я оставил тенгриев и обратился к Хурмусте: „Дайте мне это дело, помочь брату“”.

Так он молвил, и Правитель десяти областей неба и Зесе Шикер издали крик, который три раза перевернул мир, но Правитель десяти областей неба и Зесе Шикер вернули землю обратно на свое место. Тогда Нанзонг и Шумар подошли, и оба обняли Зесе.

После победы над пятнадцатиголовым мангасом все его люди, его жена Падма Рака были захвачены. Тогда сказал Шумар-герой: «Я возьму эту женщину в жены».

Пятнадцатилетний Нанзонг в ответ возразил: «Шумар, я младший брат, я бы предпочел, чтобы эта женщина стала моей женой».

[278] Но Шумар сказал: «Проси у старшего брата, чего ты хочешь, только не эту плененную женщину, в противном случае могут возникнуть омрачающие душу мысли».

Тогда Зесе Шикер встал и произнес следующие слова: «Во-первых, я - тот, кто убил Андулман-хана. Во-вторых, я - старший брат, и поэтому имею право взять эту [женщину] в супруги».

Так он молвил, и Шумар ответил следующее: «Ты всегда заботишься лишь о своей славе, Зесе. Тем не менее оставь эту женщину либо старшему, либо младшему».

Тогда Правитель встал и сказал следующее: «Какое вы имеете право требовать эту женщину? Если она должна принадлежать кому-то, то либо мне, либо Зесе Шикеру, [моему] брату».

Так он молвил, и его великий стальной меч сам собой высунулся наполовину из ножен. Тогда Правитель спросил: «Почему этот меч высунулся из ножен? Такое случилось, когда я убил двенадцатиголового мангаса. Такое случилось, когда я убил трех шарайгольских ханов. Такое случилось, когда я снес головы Андулман-хана. [279] Это случилось снова, и вынуждает меня отрубить голову этой женщине».

Так сказав, он обнажил свой великий стальной меч и отделил голову женщины от тела. Тогда Зесе Шикер спросил: «Почему ты убил эту женщину?». 
Повелитель десяти областей неба ответил: «Зесе Шикер, ты не знаешь почему? Когда этот стальной меч вылезает из ножен сам по себе, это всегда подразумевает голову злодея. Исследуй это дело, и тогда ты увидишь это сам».

Так он сказал, и Зесе Шикер, вскрыв тело ханши мечом, обнаружил пятнадцатиголового мальчика-шумнуса, чей возраст был уже девять месяцев. Тогда Зесе Шикер сказал: «Правитель десяти областей неба! Сколько вреда он причинил бы!».

Затем мальчик был уничтожен пламенем, они сожгли пятнадцатиголового Андулман-хана, спалили город и захватили людей. Гесер-хан же взял своего брата и множество людей. Они уже проделали пятнадцатидневное путешествие от места, где Зесе Шикер убил пятнадцатиголового мангаса, спустившись с неба, [280] когда они увидели приближающихся божественную ханшу Альмур, многие тысячи спутников, включая старого восьмидесятилетнего Царгина и старого Сякля, разделенные на три группы. Тогда к Правителю обратился брат Зесе Шикер: «Приближается божественная ханша, я поспешу вперед навстречу к ней».

Так он сказал, и Правитель ответил: «Правильно, мой Зесе, скачи вперед навстречу к ней». Зесе Шикер быстро отправился вперед с Нанзонгом, и весь народ был наполнен радостью, потому что увидел Зесе, и [они] сказали следующее: «Правитель едет впереди». Но старик Царгин ответил: «Что вы там говорите? Повелитель определенно не едет впереди. Возможно, это Зесе Шикер приближается». Когда он так сказал, божественная ханша [произнесла]: «В самом деле старый Царгин сказал совершенно верно, это - Зесе Шикер, скачущий на крылатой серой лошади».

«Где! Где!» - закричал старый Царгин, подстегнул своего большого буланого коня кнутом и, поспешив к Зесе Шикеру, произнес: «О, дорогой Зесе Шикер! Откуда ты так неожиданно появился? Крепок ли ты и здоров?». [281] Так он сказал, и, улыбаясь, Зесе Шикер подъехал к старику, поднял его на свою лошадь и обнял. Тогда старый Царгин произнес следующие слова: «Ты, как яростный тигр, спускающийся с вершины горы. Ты, как рассвирепевший морж в глубине моря. Эй, дорогой Зесе, куда ты торо- пишься? Откуда ты идешь? Отправившись на трёх шарайгольских ханов, ты отдал свою жизнь и теперь возвращаешься к своему Правителю, могучий Зесе».

Так он сказал, и все они приблизились, но князь Цотон [подошел] последним. Когда Зесе увидел его, он сказал: «Это пустые речи, что остальные думали обо мне, лишь Цотон и только Цотон действительно вспоминал обо мне».

Когда Зесе так сказал, остальные ответили: «Это верно!». Но князь Цотон промолчал. Повелитель десяти областей неба отправился обратно вместе с братом Зесе Шикером в свою землю, в город тройных двойных храмов $^{18}$ и ста восьми просторных крепостей. Там, в огромном дворце, был устроен радостный пир, и благородный Зесе Шикер, опорожнив двадцать чаш водки, заметил князя Цотона. [282] Зесе Шикер произнес эти слова: «Правитель десяти областей неба! Цотон внес смуту в умы священников и народа. Он уничтожил благородного Зесе, привел священников и народ в шаткое положение, опечалил душу Правителя и разрушил все. Черна, как сажа, твоя душа, злобный Цотон! Подчиняясь трем нечестивым ханам, ты бросил Правителя и отнял мою жизнь и тело. За этот причиненный вред я съем твою плоть».

Когда он, так говоря, обнажил свой меч, Цотон был охвачен ужасом. «О, горе мне, Правитель!». Так закричав, он спрятался под кроватью.

Тогда Правитель произнес следующие слова: «Дорогой Зесе, не убивай злодея! Если ты убьешь его, что же нам останется? Если его лишить жизни, ты больше не победишь десять видов зла».

Так он молвил, и Зесе Шикер произнес следующие слова: «Правитель десяти областей неба, все десять зол наполняют злодея Цотона. Я никогда не видел, чтобы он был впереди в бою. Разрушение золотого жилища - это его работа. [283] То, что ты потерял божественную супругу, - это его рук дело. То, что я, расставшись с Правителем десяти областей, потерял жизнь и тело, -

${ }^{18} \mathrm{Hem}$. dreifach gedoppelten Tempels. Возможно, здесь ошибочно написано dreifach 'тройных' вместо dreizehn 'тринадцать'. В переводе А. М. Позднеева: он построил тринадцать драгоценных храмин. - прим. переводчика. 
его работа. Ты, зловредный Цотон, предал тридцать героев, обманул священников и народ и рассеял всех нас. Согласно воле трех шарайгольских ханов ты принес нам всем несчастье, зловредный Цотон. Как я могу забыть твои преступления?»

Так говоря, Зесе Шикер встал, и князь Цотон снова лишился чувств ${ }^{19}$.

Тогда Правитель десяти областей неба сказал: «Мой Зесе Шикер, подожди! Не подобает его убивать. Дух Цотона поддерживает нас, даже когда мы спим, напоминает нам, когда мы забыли, и позволяет нам сейчас наслаждаться едой. Ничего бы не произошло без Цотона. Зловредный Цотон - один из тысячи моих хубилганов. Без силы моего благословения Цотон, чей ум черен, уже давно был бы уничтожен. Почему я всегда его спасал, теперь вы увидите сами».

Когда народ ушел, Правитель сказал: «Подойди, Цотон!». [284] Так он молвил, и князь Цотон подошел, упал и предстал пред

${ }^{19}$ В оригинале сказано: «Он лежал посередине, между бодрствованием и небодрствованием».

\section{Заключение}

1. Предположительно причина, по которой Б. Бергман перевел название двух песен «Гесера» как «Богдо Гесер-хан. Монгольское религиозное сочинение в двух книгах», заключается в том, что название включало в себя слово «судур» или «цадиг», подобно тому, как в случае с «шойтеровской» рукописью об Андулма-хане.

2. Мы предполагаем, что Я. И. Шмидт был знаком с письменным текстом калмыцкой версии «Гесера», с которой работал Б. Бергман. Я. И. Шмидт пишет о том, что Б. Бергман неверно перевел слово «хошо-

\section{Источники}

НА КалмНЦ РАН - Geser boqdo xānituuǰ // Научный архив Калмыцкого научного центра РАН. Шифр С(Калм) Г431, 12500.

\section{Литература}

Брагинский 1955 - Брагинский И. С. Об изучении эпического творчества народов Советского Востока (Гургули и Гэсэр) // Советское востоковедение, 1955. № 3. С. 18-35. ликом Правителя, и Правитель десяти областей неба стал одним с князем Цотоном. Тогда Зесе Шикер понял это и произнес: «Какой же ты счастливый человек, что правитель защищает тебя!». Так сказав, он вложил свой меч обратно в ножны.

Затем Правитель десяти областей даровал Зесе желто-пегую лошадь мангаса, которая обладала силой тринадцати драконов. Девятерной панцирь мангаса он отдал герою Шумару. Большую серую лошадь Зан-тушимэла он дал старому Царгину, а красный, как пламя, панцирь - пятнадцатилетнему Нанзонгу. Точно так же он сделал подарки всем другим героям. После того, как все это было сделано, наводящий ужас Гесер-хан стал жить в золотой земле Нулум, в своем внутреннем дворце, в соответствии с образом святого тэнгэри, умиротворенно и счастливо.

Повелитель десяти областей неба, наводящий ужас Богдо Гесер-хан уничтожил корень десяти видов зла, победил пятнадцатиголового мангаса, вернул брата Зесе Шикера и осчастливил все существа.

Книга завершена.

чи» как «безрассудный» или «отчаянный» вместо «командующего военным подразделением». Такое замечание возможно только в случае, если Я. И. Шмидт был знаком с письменным текстом, с которого Б. Бергман сделал перевод.

3. При сопоставлении русского перевода девятой песни «Гесера» А. М. Позднеева и немецкого перевода этой же песни Б. Бергмана обнаруживается большое сходство между переводами Б. Бергмана и А. М. Позднеева. Это также поддерживает гипотезу о письменной природе оригинала песен «Гесера», переведенных Б. Бергманом.

\section{Sources}

Geser boqdo xāni tuuǰi: The Story of King Geser the Great. At: Kalmyk Scientific Center (RAS). Archival call number: С(Калм) Г431, 12500. (In Oirat)

Козин 1935 - Козин С. А. Гесериада. Сказание о милостивом Гесер Мерген-хане, искоренителе десяти зол в десяти странах света. М.; Л.: Изд-во АН СССР, 1935. $245 \mathrm{c}$. 
Митруев 2020 - Митруев Б. Л. Б. Бергман и его труд о калмыках и калмыцкой культуре // Бюллетень Калмыцкого научного центра PAH. 2020. № 4. C. 176-202.

Неклюдов 1984 - Неклюдов С. Ю. Героический эпос монгольских народов. Устные и литературные традиции. М.: Наука, 1984. 309 с.

Неклюдов, Тумурцерен 1982 - Неклюдов С. Ю., Тумуриерен Ж. Монгольские сказания о Гесере. Новые записи. М.: Наука, 1982. 373 с.

Өөрд Геср - Өөрд Геср. Шинжәнә өөрднрин баатрльг дуулвр (= Ойратский Гесер: Героический эпос синьцзянских ойратов). Элиста: КИГИ РАН, 2014. 210 с. (На калм. яз.)

Позднеев 1896 - Позднеев А. М. Калмыцкие сказки VII (Текст и перевод) // Записки восточного отделения Императорского русского археологического общества. СПб.: Тип. Имп. Акад. наук, 1896. Т. IX. C. 41-58.

Попов 1847 - Попов A. B. Грамматика калмыцкаго языка. Казань: Университетская типография, 1847.390 с.

Тимковский 1824 - Тимковский Е. Ф. Путешествие в Китай через Монголию в 1820 и 1821 годах. Часть первая: Переезд до Пекина. СПб.: Тип. мед. департ. Мин-ва внутр. дел, 1824.388 c.

\section{References}

Bergmann B. Nomadische Streifereien unter den Kalmüken in den Jahren 1802 und 1803. Part 3. Riga: C. J. G. Hartmann, 1804. 302 p. (In Germ.)

Braginsky I. S. Koroghlu and Gesar: epic poetry of Eastern Soviet peoples revisited. Sovetskoe Vostokovedenie. 1955. No. 3. Pp. 18-35. (In Russ.)

Chagdurov S. Sh. The Geseriad and Its Origins: A Comparative Historical Study of the Ancient Vocabulary. Novosibirsk: Nauka, 1980. 272 p. (In Russ.)

Heissig W. Geser-Studien Untersuchungen zu den Erzählstoffen in den neuen Kapiteln des mongolischen Geser-Zyklus. In: Abhandlugen der Rheinish-Westfalischen Akademie der Wissenschaften. Vol. 69. Göttingen: Westdeutscher Verlag, 1983. 530 p. (In Germ.)

Khundaeva E. O., Badmatsyrenova D. B. The textual criticism of the records about Geser in the Old Mongolian writing. Philological Sciences. Issues of Theory and Practice. 2016. No. 11(65): in 3 parts. Part 1. Pp. 168-172. (In Russ.)

Kozin S. A. The Geseriad. The Tale of the Merciful Geser Mergen Khan, Eradicator of Ten Evils in
Хундаева, Бадмацыренова 2016 - Хундаева Е. О., Бадмацыренова Д. Б. Текстология списков о Гэсэре на старомонгольской письменности // Филологические науки. Вопросы теории и практики. Тамбов: Грамота, 2016. № 11(65): в 3-х ч. Ч. 1. С. 168-172.

Чагдуров 1980 - Чагдуров С. Ш. Происхождение Гэсэриады. Опыт сравнительно-исторического исследования древнего словарного фонда. Новосибирск: Наука, Сиб. отд-ние, 1980. $272 \mathrm{c}$.

Bergmann 1804 - Bergmann Benjamin. Nomadische Streifereien unter den Kalmüken in den Jahren 1802 und 1803. Dritter Theil. Riga: C. J. G. Hartmann, 1804. 302 s.

Heissig 1983 - Heissig Walther. Geser-Studien Untersuchungen zu den Erzählstoffen in den «neuen» Kapiteln des mongolischen Geser-Zyklus // Abhandlugen der Rheinish-Westfalischen Akademie der Wissenschaften. Bd. 69. Göttingen: Westdeutscher Verlag, 1983. $530 \mathrm{~s}$.

Schmidt 1839 - Schmidt Isaac Jacob. Die Thaten Bogda Gesser Chan's, des Vertilgers der Wurzel der zehn Übel in den zehn Gegenden: eine ostasiatische Heldensage. St. Petersburg, Leipzig: bei Leopold Voss, 1839. $287+16$ s.

Ten Countries of the World. Moscow; Leningrad, 1935. (In Russ.)

Mitruev B. L. B. Bergmann and his work on Kalmyks and Kalmyk culture. Bulletin of the Kalmyk Scientific Center of the Russian Academy of Sciences. 2020. No. 4. Pp. 176-202. (In Russ.) DOI: 10.22162/2587-6503-2020-4-16-149-175

Neklyudov S. Yu. Heroic Epic of Mongolic Peoples: Oral and Literary Traditions. Moscow: Nauka, 1984. 309 p. (In Russ.)

Neklyudov S. Yu., Tumurtseren J. Mongolian Tales of Geser. New Records. Moscow: Nauka, 1982. 373 p. (In Russ.)

Popov A. B. Kalmyk Grammar. Kazan: Imperial Kazan University, 1847. 390 p. (In Russ.)

Pozdneev A. M. Kalmyk tales: part VII (text and translation). Zapiski vostochnogo otdeleniya Imperatorskogo russkogo arkheologicheskogo obshchestva. 1896. Vol. IX. Pp. 41-58 (In Russ.)

Schmidt I. J. Die Thaten Bogda Gesser Chan's, des Vertilgers der Wurzel der zehn Übel in den zehn Gegenden: eine ostasiatische Heldensage. St. Petersburg, Leipzig. 1839. $287+16$ p. (In Germ.) 
The Oirat Geser Tradition (Öörd Gesr): A Heroic Epic of Xinjiang Oirats. Elista: Kalmyk Humanities Research Institute (RAS), 2014. 210 p. (In Kalm.)
Timkovsky E. F. Journey to China through Mongolia in 1820 and 1821. Part One: Traveling to Peking. St. Petersburg: Ministry of Internal Affairs (Medical Department), 1824. 388 p. (In Russ.) 